\title{
AWARENESS REGARDING HIVIAIDS AMONG COLLEGE STUDENTS IN KHYBER PAKHTUNKHWA
}

\author{
Khan S', Fatima S², Afridi NK³ , Salhotra VS ${ }^{3}$, Jha $\mathrm{KK}^{3}$ \\ ${ }^{1}$ Federal Medical Center, Peshawar \\ ${ }^{2}$ Khyber Teaching Hospital, Peshawar \\ ${ }^{3}$ SAARC TB and HIVIAIDS Centre, Kathmandu
}

\begin{abstract}
Introduction: HIV is still a major global health problem. In 2009, globally there were an estimated 2.6 million (2.3 million-2.8 million) incident cases of HIV. According to UNAIDS in 2009 a total of 98,000 $(79,000-120,000)$ people are living with HIV in Pakistan. Pakistan was classified as a low-prevalence country with many risk factors that could lead to the rapid development of an epidemic. In 2004, a concentrated outbreak of HIV was found among Injecting Drug Users (IDUs) in Karachi, where over 20 percent of those tested were found to be infected. Prevention efforts are beginning to bear fruit, with indications of behaviour change and declines in prevalence rates in a number of high-burden countries. The study aimed to determine the level of awareness among college students regarding HIVIAIDS in Khyber Pakhtunkhwa.
\end{abstract}

Methodology: This cross sectional study was conducted in the two colleges of Peshawar. A total of sixty students were enrolled in the study thirty from each college through random sampling. The students were from second year class. One of the colleges was from Public Sector, Government College Peshawar and the other was from private sector Peshawar Model College (PMC).

Results: It was interesting to note that $60 \%$ of the students of Government (Govt.) college and $70 \%$ of the students of PMC knew that a person having a healthy look might have been infected with HIV. Seventy percent of the students of Govt. college and $60 \%$ of the students of PMC reported that there is no curative treatment for HIVIAIDS. Major source of information regarding HIVIAIDS was through TV and friends. Condoms were regarded as main protection from HIVIAIDS as 35\% of the students of Govt. College and $40 \%$ of the students of PMC reported as a method of prevention, Other preventive methods were also reported by the students.

Conclusion: The study depicted that there remain gaps in certain areas of awareness of the students which needs initiation of HIVIAIDS awareness programmes among college students.

Key words: HIVIAIDS, IDUs, Peshawar

\section{INTRODUCTION}

HIV is still a major global health problem. Since the first cases were recorded in 1981, acquired

\begin{tabular}{l}
\hline Correspondence: \\
Dr. Shahid Khan \\
MBBS, MPH (Melbourne, Australia) \\
Medical Officer, Federal Medical Centre \\
Peshawar, Pakistan \\
\hline
\end{tabular}

immunodeficiency syndrome (AIDS) and its causative agent, the human immunodeficiency virus (HIV), have taken an enormous toll around the world. In 2009, globally there were an estimated 2.6 million (2.3 million-2.8 million) incident cases of HIV. The decline in mortality due to HIV is about $25 \%$ and reflects the increased availability of antiretroviral therapy, as well as care and support, to people living with HIV, particularly in middle- 
and low-income countries; it is also a result of decreasing incidence starting in the late 1990s.

According to UNAIDS in 2009, a total of 98,000 $(79,000$ - 120,000) people were living with HIV in Pakistan. The mortality due to AIDS is placed at $5,800(4,500-7,400) .{ }^{2}$ Pakistan was classified as a low-prevalence country with many risk factors that could lead to the rapid development of an epidemic.

Knowledge about HIV is the first step to avoid its transmission. Yet less than one third of young men and only a fifth of young women in developing countries know basic facts about the virus. Although condom use has gained acceptance in some countries, global use remains low, especially among young adults in developing countries. ${ }^{3}$

Worldwide efforts to address HIVIAIDS have advanced in recent years. Prevention efforts are beginning to bear fruit, with indications of behaviour change and declines in prevalence rates in a number of high-burden countries. Many countries-supported by the WHO/Joint United Nations Programme on HIVIAIDS (UNAIDS) ' 3 by $5^{\prime}$ Initiative and the efforts of many other partnershave also made significant progress in expanding access to antiretroviral therapy. Still much more remains to be done if the goal of universal access is to be achieved. Global coverage of many of the key health sector interventions against HIVI AIDS remains low, and growth in the numbers of new infections and people in need of treatment continues to outpace the capacity of health services to respond. Global financial resources also fall short of what will be needed to achieve universal access, and the sustained political commitment needed to tackle AIDS over the long term is still lacking in some countries. ${ }^{4}$

Lack of awareness and fear of HIVIAIDS create key apprehensions among students and general public and may generate a barrier to successful educational endeavors regarding the disease. This might lead to a range of unfavorable outcomes such as seeking advice or reluctance to treat AIDS patients. ${ }^{5}$ Concerns about AIDS panic have among other things been linked to lack of appropriate knowledge about HIV and its transmission routes. ${ }^{6}$
The study was conducted with the aim to determine the level of awareness among college students regarding HIVIAIDS in Khyber Pakhtunkhwa.

\section{METHODOLOGY}

This cross sectional study was carried out from January - March 2010 among two colleges of Peshawar, Khyber Pakhtunkhwa, namely; Peshawar Model College, Peshawar and Government college, Peshawar.

The study population consisted of students of second year class of these two colleges. Sixty students were enrolled in this study; thirty from each college.

\section{Sampling strategy}

From each college 30 students were randomly selected from the total of 60 students from second year class. Each of the 30 students was explained about the purpose of the study. Informed consent was taken from all the participants. One of the colleges was of public sector (Govt. college Peshawar) while the other belonged to private sector (Peshawar Model college, Peshawar). The questionnaires were filled by experienced data collectors from the students.

Those students who gave consent to take part in the study were included while those who refused to give consent were excluded from the study.

Data was entered and analyzed in Statistical Package for Social Sciences (SPSS 14). ${ }^{7}$

Mean and standard deviations were calculated for continuous variables while frequencies and percentages were calculated for categorical variables.

\section{RESULTS}

The response rate of the sixty students enrolled was $100 \%$. Overall mean age of the students was approximately twenty years with students from Govt. college (18 yr) younger than that of PMC (20 yr). 
It was observed that $p$-value was not significant regarding the responses of the students of the two colleges, hence it was concluded that the responses for the awareness regarding HIVIAIDS were similar for the students of the two colleges.

Table 1 describes the knowledge regarding HIV/ AIDS among college students in Peshawar. It is interesting to note that $60 \%$ of the students of Govt. College and $70 \%$ of the students of PMC knew that a person having a healthy look might be having HIV in his body. But on the contrary $80 \%$ of the students of Govt. college and $78 \%$ of the students of PMC said that they were not at risk of contracting HIV. This might be due to the reason that health education regarding HIVIAIDS was not imparted in educational institutions and needs revision of their curricula.

Table 1. Knowledge regarding HIVIAIDS among college students in Peshawar

\begin{tabular}{|c|c|c|c|}
\hline Variable & $\begin{array}{l}\text { Govt. } \\
\text { College }\end{array}$ & PMC & Total \\
\hline \multicolumn{4}{|c|}{ Healthy looking man may have HIV*** } \\
\hline Yes & $18(60 \%)$ & $21(70 \%)$ & $39(65 \%)$ \\
\hline No & $09(30 \%)$ & $06(20 \%)$ & $15(25 \%)$ \\
\hline Don't know & $03(10 \%)$ & $03(10 \%)$ & $06(10 \%)$ \\
\hline \multicolumn{4}{|c|}{ Risk of contracting HIV by the respondents } \\
\hline Yes & $04(15 \%)$ & $03(10 \%)$ & $07(12 \%)$ \\
\hline No & $24(80 \%)$ & $23(78 \%)$ & $47(78 \%)$ \\
\hline Don't know & $02(05 \%)$ & $04(12 \%)$ & $06(10 \%)$ \\
\hline \multicolumn{4}{|c|}{ HIV is not transmitted by } \\
\hline Hand Shaking & $10(35 \%)$ & $11(25 \%)$ & $21(35 \%)$ \\
\hline $\begin{array}{l}\text { Eating in same } \\
\text { utensils }\end{array}$ & $06(20 \%)$ & $04(15 \%)$ & $10(17 \%)$ \\
\hline $\begin{array}{l}\text { Studying together } \\
\text { in college }\end{array}$ & $14(45 \%)$ & $15(50 \%)$ & $29(48 \%)$ \\
\hline \multicolumn{4}{|c|}{ Preventive measures from HIV } \\
\hline $\begin{array}{l}\text { Safe blood } \\
\text { transfusion }\end{array}$ & $09(30 \%)$ & $08(25 \%)$ & $17(28 \%)$ \\
\hline Using condoms & $10(35 \%)$ & $12(40 \%)$ & $22(37 \%)$ \\
\hline Sterilized syringes & $03(10 \%)$ & $03(11 \%)$ & $06(10 \%)$ \\
\hline New razors/blades & $08(25 \%)$ & $07(24 \%)$ & $15(25 \%)$ \\
\hline \multicolumn{4}{|c|}{ Is treatment for HIV present } \\
\hline Yes & $09(30 \%)$ & $12(40 \%)$ & $21(35 \%)$ \\
\hline No & $21(70 \%)$ & $18(60 \%)$ & $39(65 \%)$ \\
\hline
\end{tabular}

One of the main findings was that majority of the students believe that HIV was transmitted through unsafe sexual activities while knowledge regarding other routes of transmission is lacking. Condoms were regarded as main protection from HIVIAIDS as $35 \%$ of the students of Govt. College and $40 \%$ of the students of PMC reported it as a method of prevention, Other preventive methods were also reported by the students. It is also interesting that $70 \%$ of the students of Govt. College and $60 \%$ of the students of PMC reported that there is no treatment for HIVIAIDS.

Figure 1 shows the different routes of HIV transmission responded by the students. It is evident from the graph that unsafe sex is accounted as the major route of transmission. And approximately $60 \%$ of the Govt. College and $50 \%$ of the PMC responded that unsafe sex is major route of transmission while contaminated blood transfusion accounted for $10 \%$ (Govt. College) and 05\% (PMC) as route of transmission for HIV.

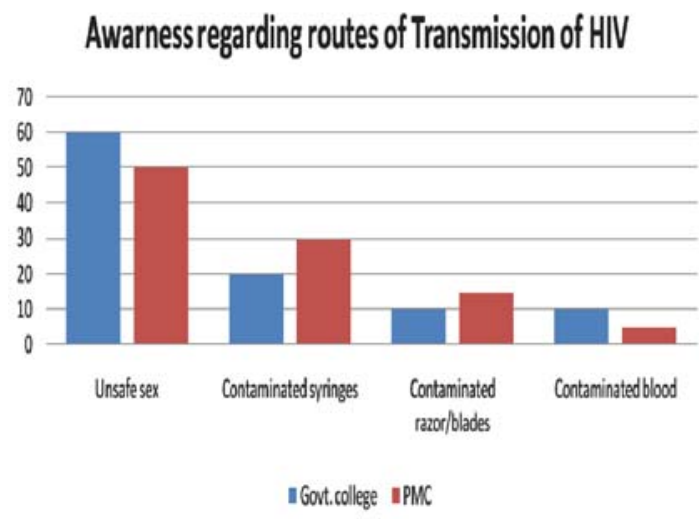

Figure 1. Routes of HIV transmission

Sources of information regarding HIV infection are depicted in figure 2. Television for the Govt. College $(35 \%)$ \& PMC $(45 \%)$ and friends for the Govt. College (45\%) \& PMC (40\%) were the most frequently reported source of information regarding HIV. While radio for both Govt. College \& PMC $(5 \%)$ was the less frequently reported source of information regarding HIV infections.

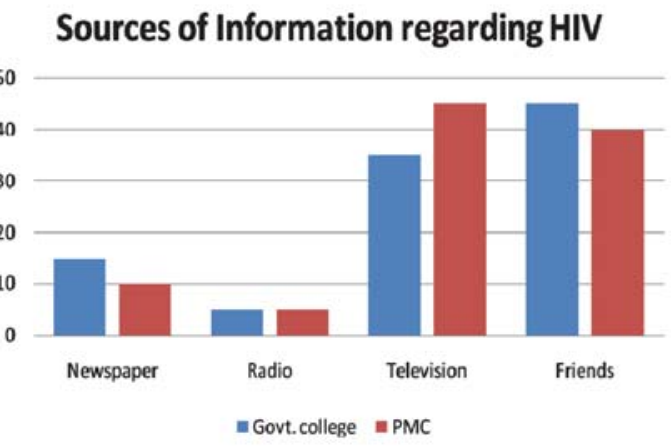

Figure 2. Sources of information regarding HIV infection 


\section{DISCUSSION}

This study compared the awareness level regarding HIV among two groups of college students in Peshawar. The study enrolled college students with the assumption that a younger age group of population was targeted and who were thus prone to risky behavior.

The study showed that almost all of the students of the two colleges have heard of HIVIAIDS. Similar observation was made in other studies conducted in Africa. ${ }^{8}$

Friends and television were the most frequently reported sources of HIV information among both public and private college students. TV was considered to be a major source of information regarding HIVIAIDS.

The sources of HIVIAIDS information reported in this study are similar to those identified previously among students/dental health care workers from USA as well as in students of medical subjects from Iran and Pakistan. ${ }^{9,10}$ Similar findings regarding media as a main source of information for HIV/ AIDS was found in a study conducted in Sudan and Ethiopia. ${ }^{11,12}$

In our study majority of the students considered unsafe sex as the major route of transmission while contaminated instruments is accounted as low risk route for transmission. In a study from United Kingdom, dentists demonstrated good knowledge regarding oral lesions associated with HIV and AIDS, but were less familiar with HIV and AIDS transmission routes. ${ }^{13}$

Generally, the respondents seem to have favorable awareness level on prevention of the disease. Prevention strategies are well known in developed countries, however, recent epidemiological and behavioral studies in Europe and North America have suggested that a substantial minority of young people continue to engage in high-risk practices and that despite HIVIAIDS knowledge; young people underestimate their own risk of becoming infected with HIV.
This study depicts that knowledge regarding transmission of HIV through hand shaking and eating in utensils of HIV patients is low and is similar to the results of a study conducted in India by G.S. Basavayya in his study he observed that $20 \%$ \& $15 \%$ girls had false notion that HIV spread by kissing, playing together and through mosquito bites. $^{14}$

A very significant finding of this study was that all the students who participated in this study had a good level of awareness regarding HIVIAIDS and studies conducted in India had also reported high level of knowledge among participants regarding HIVIAIDS. ${ }^{15}$

\section{CONCLUSION}

The study depicted that there remain gaps in the certain areas of awareness of the students which needs initiation of HIVIAIDS awareness programmes in the first year of their studies. Health education regarding HIVIAIDS transmission and prevention should be included in the curricula of education. Hence, appropriate health education should be given in a way to bring behavioral change targeting at individual risk behavior.

However, it is suggested to conduct a large scale study conducting different strata of the younger population before considering implementation of the above mentioned recommendation,

\section{REFERENCES}

1. UNAIDS, HIV/AIDSGlobal Report2010.Availableon URL http://www.unaids.org/documents/20101123_ GlobalReport_em.pdf

2. UNAIDS, HIV \& AIDS Estimates 2009. Available at URL: http://www.unaids.org/en/regionscountries/ countries/pakistan/

3. Millennium Development Goals (MDGs) Goal 6. Available from URL http://www.un.org/ millenniumgoals/pdf/MDG_FS_6_EN.pdf

4. World Health Organization, HIVIAIDS Programme, Towards Universal Access by 2010. How WHO is working with countries to scale-up HIV prevention, treatment, care and support. 2006 
5. Kopacz DR, Grossman LS, Klamen DL. Medical students and AIDS, knowledge, attitudes and implications for education. Health Educ Res 1999;14:1-6.

6. Kemppainen JK, Dubbert PM, McWilliams P. Effects of group discussion and guided patient care experience on nurses' attitudes towards care of patients with AIDS. J Adv Nurs 1996;24:296-302.

7. SPSS Inc. Headquarters $233 \mathrm{~S}$. Wacker Drive, 11 th floor, Chicago Illinois Statistical Package for Social Sciences SPSS (Computer Program).

8. Taffa N. Sexual activity of out-of-school youth and their knowledge and attitude about STDs and HIV/ AIDS in Southern Ethiopia. Ethiop J health Dev 1998;12:17-22

9. Shaikh FD, Khan SA, Ross MW, Grimes RM. Knowledge and attitudes of Pakistani medical students towards HIV-positive and/orAIDS patients. Psychol Health Med 2007;12:7-17

10. Askarian M, Mirzaei K, Assadian O. Iranians' attitudes about possible human immunodeficiency virus transmission in dental settings. Infect Control Hosp Epidemiol 2007; 28:234-7

11. Nasir EF, Anne Nordrehaug Åstrøm AN, David J, Ali RW. HIV and AIDS related knowledge, sources of information, and reported need for further education among dental students in Sudan- a cross sectional study. BMC Public Health 2008; 8:286

12. Geiger S. Sexual behavior \& knowledge of HIV/ AIDS \& other STDs. A survey of senior high school students Ethiop J Health Dev. 1990;4:123-131

13. Crossley ML. An investigation of dentists' knowledge, attitudes and practices towards HIV+ and patients with other blood-borne viruses in South Cheshire, UK. Br Dent J 2004;196:749-54.

14. Basavayya GS et al. Awareness of HIVIAIDS among medical students. IJPH 2005;49: 31-32.

15. Lal SS, Vasan RS, Sarma PS, Thankappan KR. Knowledge and attitude of college students in Kerala towards HIVIAIDS, sexually transmitted diseases and sexuality. Natl Med J India 2000;13:231-6. 